\title{
Explore the French language teaching practice model based on the ability of language
}

\author{
Hui WU \\ School of Foreign Languages \\ Wuhan Textile University \\ Wuhan, Hubei 430073 China
}

\begin{abstract}
According to the students' language skills in French professional status and employment needs, traditional French teaching model is gradually showing some drawbacks. According to the characteristics and needs of the teaching of French and combined with the practical experience of classroom teaching language classes, we explore how to enrich the teaching content of the means to diversify the practice of the process, respect for differences in teaching objects, and integrate to improve their level of knowledge and language skills.
\end{abstract}

Keywords- Language ability, French teaching, practice mode

\section{INTRODUCTION}

As the development of exchanges between China and France has become increasingly frequent, many small French languages have become one of the hottest professions professional. However, previous knowledge of the kind of language-centered teaching mode has been gradually unable to meet the demand. In order to successfully achieve the communicative purpose, French learners not only need to have a solid knowledge of the language system, but also have accurate, decent communication skills in French. So, after years of French study, learners can use English to communicate effectively, and you need to develop pragmatic competence in the French language teaching.

Pragmatics is a branch of linguistic, language is a research center of the emerging field of meaning. The main research is to understand and use language. Interlanguage pragmatics is an interdisciplinary which began in the 1980s, it is the second major study of the behavior of non-native speakers of the language and understand their behavior. In recent years, foreign scholars interlanguage pragmatics have done a lot of research, of which there are many scholars to develop pragmatic competence explored, but these studies are based on the language as a second language environment for foreign language learning and it is no much help to domestic language learning. So, we will develop pragmatic competence into Chinese teaching of French, which will become a new topic to be studied.

\section{SIMILAR PHRASE IN FRENCH AND ENGLISH}

French and Chinese have metonymy and metaphor which has the use of such means, through this way, people can reflect the kind of thinking when they speak. The expression of organ terms, in French and Chinese there are also some connections, according to the analysis and comparison, we can find people to create similarities in language process and deepen the understanding of the language and culture. Such as the head, French latete is the core of people's thinking, which is represented in more than one language that is wisdom Merciful, the Chinese did not mind using them to represent a person good at thinking, stupid, and in French, perdre Iatete has the same meaning. The antisense of this remark is avoir toute satete, which translated meaning is full of wisdom and so on. This also can reflect that, in metaphorical terms of body organs, French and Chinese have certain similarities. Similarly, among the French, the back is 1e dos, among the Chinese, the back often have to bear the responsibility, habit or bear the burden of sexual expression and other related tools, the same in French has a similar expression, such as en avior plein dos, which indicates that people overwhelmed unbearable burden of the body, such as the meaning. In addition, that the French were on the back also expressed the habit of e tre 1e dos au mur etc. similar to that metaphor is a desperate people who were trapped, no way out, at this point, French and Chinese can be described with the same purpose.

In addition, among the French for five palaces, it also has a habit of expressing relevant term, there are some similarities with the Chinese. Such as the eyes, French lesyeux, there are metaphors que 1e ventre in French, which implies that people with big eyes and a small stomach, is that people do not know the depth of representation, which is a French idiom similar expression, similar to the Chinese. In addition, the French nose, is 1e nez, the following phrase is avoir 1e nez sur son travail, literal translation of the meaning of the nose on the job means that people are nosy, or say that love is nothing to know and so on. So, French and Chinese idioms have certain similarities to express in terms of a similar body organs, its comparative analysis can help learners better grasp French cultural connotations to deepen the understanding of the French language. 


\section{2 MAJOR PROBLEMS EXISTING IN FRENCH TEACHING PRACTICE CURRENTLY}

\section{A. Timid afraid of difficulties, lack of confidence}

Timid and gear are an emotional beginner who is prone to the French. As a simple example, we will learn the very beginning 35 phonemes in French, some factors of articulation are used when we do not speak Chinese or rarely used, the student is difficult to accurately pronounce; while reading aloud, there is a lot of need for joint French chant, even the situation of the tone, coupled with the requirements, French speech rate is also relatively fast, unlike the requirements of this series which make it easy for beginners to produce timid fear of hardship, they will not open the mouse to speak for fear of mistakes, or even lose the confidence to continue to learn French.

\section{B. Isolated memory, hard to inflect}

Students can only stay in the isolated memory of vocabulary and knowledge, and passive mechanical imitation and practice level, the actual process of interaction is difficult to learn the language knowledge provided in the effective application of the scene, plus the traditional literacy teaching ideas in the presence of heavy and light heard heavy written language, spoken language tends to be light, it is prone to "export difficult", "dumb English" phenomenon. Students who have good scores in French exam often reflect, in practice sessions they can not turn their brains quickly. For example, in expression of a sentence, students should consider the word choice, verb displacement, sentence choices, a variety of complex problems, and so it felt like "Rugged Mountain Path." In fact, this is because we usually lack knowledge on learning the regularly utilize of language.

\section{Mindset and cultural differences}

Chinese and French is significantly different on the syntactic structure. As the Chinese say, "I love you" in French is "Je t'aime", according to the order-by-word translation is, "I love you", which is French direct object personal pronouns in advance of the phenomenon. Beginners should therefore have negative migration and antiinterference ratio of French mother tongue learning, which is a big factor affecting our French capabilities. The other is the communication difficulties caused by cultural differences, due to the lack of relevant background knowledge and grasp of cultural knowledge, students often occur in the communication "so as not to pull its weight", "lied" and other embarrassing situation.

\section{Weigh classes, light practice}

Many students have undue reliance on classroom while ignoring the self-practice when learn and use the second class. We know that language teaching and language practice in the classroom Bijing is limited, in order to truly improve listening and speaking skills and interpersonal skills, you must learn to play the body and spirit of a sense of ownership, and actively carry out independent practice and practice the language.
How to change this situation, the transition to the examination of language learning students has heard excellent ability in French, this is what our educators should actively think about.

\section{CONSTRUCTION OF A NEW MODEL OF TEACHING FRENCH}

In traditional foreign language classroom, the main task is to recite and memory imparted knowledge, there is less interaction between teachers and students about the opportunity to exercise, it is difficult to cultivate students' communicative competence of the teaching objectives. Students learning in the classroom knowledge are more suitable candidates, rather than the actual use of communicative environment. In addition, many applicationoriented undergraduate education in French teaching requirements are currently facing increased difficulties to reduce allocated hours and to ensure the quality of teaching in this case, French students' good communication skills is to conform to application-oriented education French personnel training requirements, it must deepen the educational reform, and actively explore to develop students self-learning ability and communicative competence in French new model applied undergraduate teaching of French as a center.

\section{A. Establish a "student-centered, teacher-led" teaching philosophy}

In traditional teaching, teachers in leadership positions of authority and control of the dominant position of students is being neglected, it becomes a "passive recipients of external stimuli" and "instill knowledge objects." The rapid development of constructivism is represented by the rise of new technologies and modern education learning theory, the traditional relationship between "teaching" and "learning" has undergone a fundamental change: the students become the main center of learning and cognition by the traditional passive recipients to active participants, teachers from teaching and instilling are into the identity of the organizers of the learning process of students, mentors, help and facilitator. To this end, teachers should have to change the past, "mouthpiece" of teaching habits, carried out studentcentered teaching activities, realize the play of the main initiative of learners, to stimulate students interest in learning and help students develop motivation; It gradually reduces the external control, increases students' self-control the opportunity to learn the process, develops students' ability to take the initiative to acquire knowledge, to help students learn to think independently and self-management, mastery learning approach, the owner and responsible person are to do their own learning, but also learn to cooperate with others, and ultimately to the knowledge meaning construction; we create situations in line with the requirements of the teaching content and tips link between old and new knowledge which leads to help students have some means of cognitive structures to construct new knowledge; We have organizational collaborative learning, discussions and exchanges to guide the process, and make it conducive to the construction of meaning toward the direction of development, so that the entire study group together can complete the 
construction of the meaning of knowledge learned; we change the traditional concept evaluation, establish open, multi-dimensional concept evaluation; we have constantly teaching methods, teaching techniques for reform to adapt to the information age requirement for foreign language teaching.

It should be noted that, in teaching practice, one-sided emphasis on the dominant position of students is not desirable, the leading role of teachers can not be ignored, if we do not have the teacher's guidance, students will certainly be caught the blind, so we can not guarantee the quality of teaching and teaching effect. Therefore, we should adhere to the "student-centered, teacher-led" philosophy of education, it is necessary to emphasize the learners' cognitive function, but also to pay attention to the leading role of teachers, only organically combining the two can we reach the maximum limits to play both sides of initiative and creativity to achieve the best teaching results.

\section{B. Practice is essential}

We actively cultivate learning backbone to promote collective learning quality improved steadily. Practice has proved that a general academic classes showing two small middle large olive ball. That means that good and poor is basically a minority, while the majority of students are in the intermediate state. Each one student achievement is actually presented a dynamic process, and never static. Teachers must be equal treatment of every student, not sparse achievement crossed pro. Teachers should accurately grasp the individual differences of students, so they can be individualized. While actively developing a "learning team leader", "little teacher" to help poor students grades moment, good student bring up the learning atmosphere, on the part of students, we not only solve the puzzles of lack of classroom time, but also improve teaching relevance and effectiveness, and gradually develop independent learning culture classes. We organize students to participate actively in class and outside of teaching activities, consolidate knowledge in practice by inspiring students to attract students running the Learn, operating comments, quizzes and other activities. When students find their own lack of knowledge of the activities of naturally occurring learning needs, we stimulate enthusiasm for learning. It can be considered by the vertical and horizontal communication to achieve the purpose of teaching and teaching effectiveness unity, the so-called vertical refers to high school students in the lower grades of French language learning experience of each other, so that excellent seniors guide school brother, school girl who do not take detours. The so-called lateral is to break classes, colleges and schools of imprisonment, going out, please come in, to do with the exchange between grades, good communication between bilingual colleges with the French department through the activities, it is also to select the appropriate time, the pilot opened the door for the needs of teaching, teaching base to build off-campus, and the arrange for students to leave the campus, or some representative who will be invited to campus, classroom teaching is always combined with social practice, so that students enjoy in practice use knowledge fun, and grow with the society, knowledge society, social service skills. Establish the dominant position of students in teaching is a new teaching philosophy, and its core is the students' selflearning, self-development. In the teaching process, teachers should do more knowledge-looking guidance, counsel and dispel misunderstanding specific service work, and allow students to give full play to their potential and make their knowledge to get more assertive personality. Students can enjoy the fun of learning and fun environment where quality is educational to achieve "to me" to "I want to learn" fundamental change. Technology and education have tremendous charisma, young teachers are not unworthy of the times, we hard work in China outside this fertile land, and strive to build China into outer Wen Jiabao as hoped, "unique, form their own educational philosophy and style, for the country to train more high-quality, and diverse "creative talent" hundred schools.

\section{CONCLUSION}

Today, grim employment situation is greater for college students, and foreign students have no exception. So in order to gain a firm foothold in the community, in addition to a solid grasp of the professional skills, two external integrated abilities are also essential, especially listening and speaking skills and interpersonal skills. Aiming at the two outside French teaching in various educational shortcomings, we should actively make up, improve the structure of French education, updates teaching methods, and use a variety of teaching methods to improve the quality of teachers to build a better classroom teaching model and to achieve the quality of teaching leap.

\section{REFERENCES}

[1] Zhao Jing. Effective teaching practice and reflection mode[J] In addition French teaching. Hubei Normal University (Philosophy and Social Sciences),2009,03:134-138.

[2] Jiao Yang. On how to establish the dominant position of students in the teaching activities - Research and Practice of Bilingual Teaching basic English Autonomous Learning Model [J] Jilin Huaqiao International Studies University,2009,01:92-95. .

[3] Chen Fengqin. formative assessment used in the teaching of French vocational feasibility analysis [J] Chinese school education, 2011, S1:.. 179.

[4] Chen Yan. Problem-oriented teaching mode to build[D]. Southwest University, 2013.

[5] Lifeng. Exploration and Practice Extensive French Teaching Mode [J]. French learning, 2013, 05:34-38.

[6] Zhang Mingli. Issue of university teaching French and Countermeasures[D]. Southwest University,2013.

[7] Yangyuan. Cultured French Teaching Pragmatic Competence[D]. Xiangtan University,2012.

[8] Fengkehong, Jin Hui. Use the communicative approach in the teaching of French [J]. Scientific and technological information, 2012, 30: 230 +232 . 